\title{
Przeklqác lubię - tak po góralsku. O góralach, Tatrach i Zakopanem z Bartłomiejem Jureckim rozmawia Katarzyna Chrudzimska-Uhera
}

\author{
DOI: https://doi.org/10.21697/an.9381
}

Katarzyna Chrudzimska-Uhera: Zacznę od pytania zasadniczego: czy jest Pan góralem czy ceprem?

Bartłomiej Jurecki: Płynie we mnie pół na pół czysta krew góralska i krakowska. Mama jest góralką, tata pochodzi z Krakowa. Czuję się góralem, kiedy jestem w Zakopanem, a krakusem - w Krakowie. Mam rodzinę w Krakowie, wiążę z tym miastem wspomnienia, tam też studiowałem, a w Zakopanem mieszkam, tu skończyłem szkołę, tutaj spędzam czas. Mój dziadek, Wincenty Galica, jest legendarną postacią Podhala' ${ }^{1}$, pierwszym góralem - honorowym obywatelem Zakopanego. Czuję tę góralską krew i czuję się góralem. Może nie w stu procentach, ale jednak.

Pańska fotograficzna opowieść o góralach wydaje się bliska romantycznej wizji XIX-wiecznych odkrywców Tatr i mitycznemu obrazowi tworzonemu przez Witkiewicza i innych miłośników góralszczyzny. Nie kojarzy się z obiektywnym spojrzeniem współczesnego zakopiańczyka chłodno oceniającego swoich sąsiadów.

1 Wincenty Galica (1916-2010), uczestnik kampanii wrześniowej, kurier tatrzański, więzień niemieckich obozów koncentracyjnych, po wojnie lekarz i zasłużony działacz społeczny Zakopanego.
Mam na myśli obraz górali, jaki stworzył Pan w cyklu fotografii Twardy jak skała, nagrodzonym w prestiżowym konkursie The National Press Photographers Association w 2018 r.

Pomysł cyklu zrodził się spontanicznie. W pewnym momencie zauważyłem, że jeżdżąc po Podhalu, często spotykam ludzi, którzy przypominają wyglądem tych żyjących dawno temu, tych, których możemy oglądać na starych zdjęciach, obrazach, rzeźbach. I takich, najbardziej charakterystycznych, chciałem wybrać, tych, którzy wyglądem przypominają górali sprzed lat, i na widok których - gdybyśmy zobaczyli ich np. w Australii, bez stroju góralskiego od razu byśmy zawołali: hola! przecież to jest góral spod samiuśkich Tater! Tacy są moi bohaterowie - przede wszystkim charakterystyczni pod względem urody, mają te niesamowite rysy twarzy, zagięte nosy, długie włosy, brody. Ich twarze wyrzeźbione są przez naturalne miejsce, w którym żyją - przez skoki ciśnienia, wiatr halny... Ja to też doskonale odczuwam, wpływ pogody na mnie jest bardzo duży i nie potrzebuję prognoz, żeby wiedzieć, kiedy będzie wiało albo padało. I tacy są ci moi bohaterowie. Wyrzeźbieni przez klimat i ciężką pracę. Postanowiłem, że wezmę ich do kupy, 
zbuduję serię fotografii, w której koncentrować będę się na ich twarzach.

Przyznaje Pan więc, że obraz górala stworzony i utrwalony przez sztukę (wspomniane przez Pana dawne fotografie, obrazy i rzeźby)-zgadza się z Pańską wizją Podhalan: ich fizyczności, rysów i wyrazu twarzy. Ale każde zdjęcie w cyklu uzupełnia krótki tekst prezentujący historię życia, charakteryzujący danego bohatera. Czy te opowieści są równie ważne, jak notowane przez obiektyw twarze? Czy odzwierciedlają relacje, jakie nawiązał Pan ze swoimi modelami?

To jest mój bardzo osobisty projekt. Nosiłem ten pomysł w sobie, ale czułem, że do jego podjęcia musiałem dojrzeć - jako człowiek i jako fotograf. Sam wybierałem bohaterów serii, zwracając uwagę na ich „typowy” wygląd, drugorzędne było dla mnie to, kim oni są. Następnie umawiałem się na spotkanie, czasem długo to trwało, zanim zdobyłem ich zaufanie, zanim uzgodniliśmy termin sesji. Każdy z moich bohaterów ma swoją niesamowitą historię. Byłem u ok. stu pięćdziesięciu osób, nie spotkałem ani jednej, która miałaby „złą" historię. Nawet ci, którzy całe życie siedzieli przed domem i robili skarpety, a jedyną pociechę czerpali ze swoich wnuków albo z pięknego zachodu słońca, nawet takie osoby potrafiły w rozmowach przekazać mi coś cennego. Selekcji tych historii nie robiłem. Ale moim zadaniem jest fotografowanie, a kiedy zdjęcie jest zrobione, przekazuję kontakt jednemu z ośmiorga dziennikarzy z „Tygodnika Podhalańskiego”, z którymi współpracuję. To oni przeprowadzili rozmowy, które zostały dołączone do portretów.

Serii portretów męskich Twardy jak skała odpowiada cykl Silna jak halny, prezentujący wizerunki góralek. Czego szukał Pan u kobiet?

Te dwie serie tworzą całość. Chciałem pokazać ostatnich górali, charakterystycznych, typowych, którzy wyglądają i noszą się tak, jak ci sprzed lat, jak ich przodkowie. Myślę, że za dwadzieścia, trzydzieści lat nie będziemy już na ulicy widywać tych „twardych jak skała". Natomiast w przypadku kobiet jest inaczej. W przypadku „silnych jak halny", za jakiś czas będziemy mogli powtórzyć tę serię. Kobiety, poza strojem góralskim, chustami, koralami, twarze mają podobne do kobiet $z$ innych regionów, np. tych, mieszkających nad morzem. Przyznam, że zostałem nakłoniony, żeby tę drugą serię zrobić. Każda góralka była niesamowita, czasem bardziej zainteresowana, czasem bardziej nieśmiała; były panie, których się bałem, a były i takie, przy których czułem, jakbym znowu miał babcię. Dalej noszę skarpety, które dostałem od moich bohaterek! Jednak uważam, że Twardy jak skała jest serią silniej oddziałującą na odbiorców niż seria Silna jak halny.

Z bohaterami swoich zdjęć, mieszkańcami Podhala i Spisza, nawiązuje Pan bliskie relacje, które znajdują odbicie na fotografiach i bez wątpienia podnoszą autentyzm ich przekazu. Jednym $\mathrm{z}$ takich przejmujących zdjęć jest portret podwójny Sianokosy w Rzepiskach rozpoczęte (il. 1).

To zdjęcie powstało w 2014 r., a w 2015 udało mi się zdobyć za nie wyróżnienie w konkursie National Geographic Traveler Photo. Jego bohaterowie zostali gwiazdami Rzepisk! Również dla mnie było to ważne zdjęcie i znaczące osiągnięcie zawodowe, bo fotografia - jako dzieło laureata konkursu trafiła do amerykańskiej edycji magazynu, była też prezentowana w wielu krajach.

\footnotetext{
Kolejną, niezwykłą postacią jest juhas ze Starego Bystrego...

To jeden z bohaterów serii Twardy jak skała, nie ukrywam - mój ulubiony juhas, niezwykle sympatyczny, zawsze radosny i uśmiechnięty, inteligentny i błyskotliwy. Za każdym razem, kiedy spotykam go podczas redyku w Czarnym Dunajcu, chcę
} 


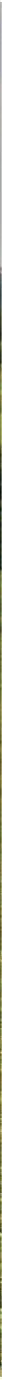

1. Bartłomiej Jurecki, Sianokosy w Rzepiskach rozpoczęte, 2014

z nim chwilę porozmawiać, bo on przekazuje pozytywne emocje. Przy okazji takiego spotkania powstało zdjęcie (il. 2), kiedy juhas wracał do domu z redyku. Zaczęliśmy żartować i skorzystałem z okazji. Zdjęcie jest udane pod względem ładunku emocji a to jest w fotografii najistotniejsze, żeby przekazać emocje. Zwłaszcza te pozytywne, zwłaszcza w tych czasach, kiedy widzimy wszędzie smutne twarze... Chociaż teraz w ogóle nie widzimy ani twarzy, ani uśmiechu, ukrytych za maseczkami... Ale jak już ktoś zdejmie maseczkę, to z reguły jego twarz jest smutna, więc takie zdjęcia teraz są bardzo potrzebne, bo śmiech jest zaraźliwy.
Wspomniał Pan redyk. Jesienny powrót pasterzy ze stadami owiec jest tematem, który często Pan podejmuje, dokumentując to wyjątkowe wydarzenie i ten magiczny czas, kiedy nowoczesny świat zdaje się ustępować miejsca tradycji. Drogi zamieniają się w szlaki przemarszu zwierząt, nad którymi czuwają nie tylko juhasi, ale i służby porządkowe, a samochody toną w morzu owiec. Niezwykłość tych zdjęć docenili nie tylko widzowie, ale też jurorzy międzynarodowego konkursu The Miami Street Photography Festival (MSPF), kwalifikując w 2020 r. Redyk w Maniowych (il. 3) do TOP 23 zdjęć nadesłanych z całego świata. 


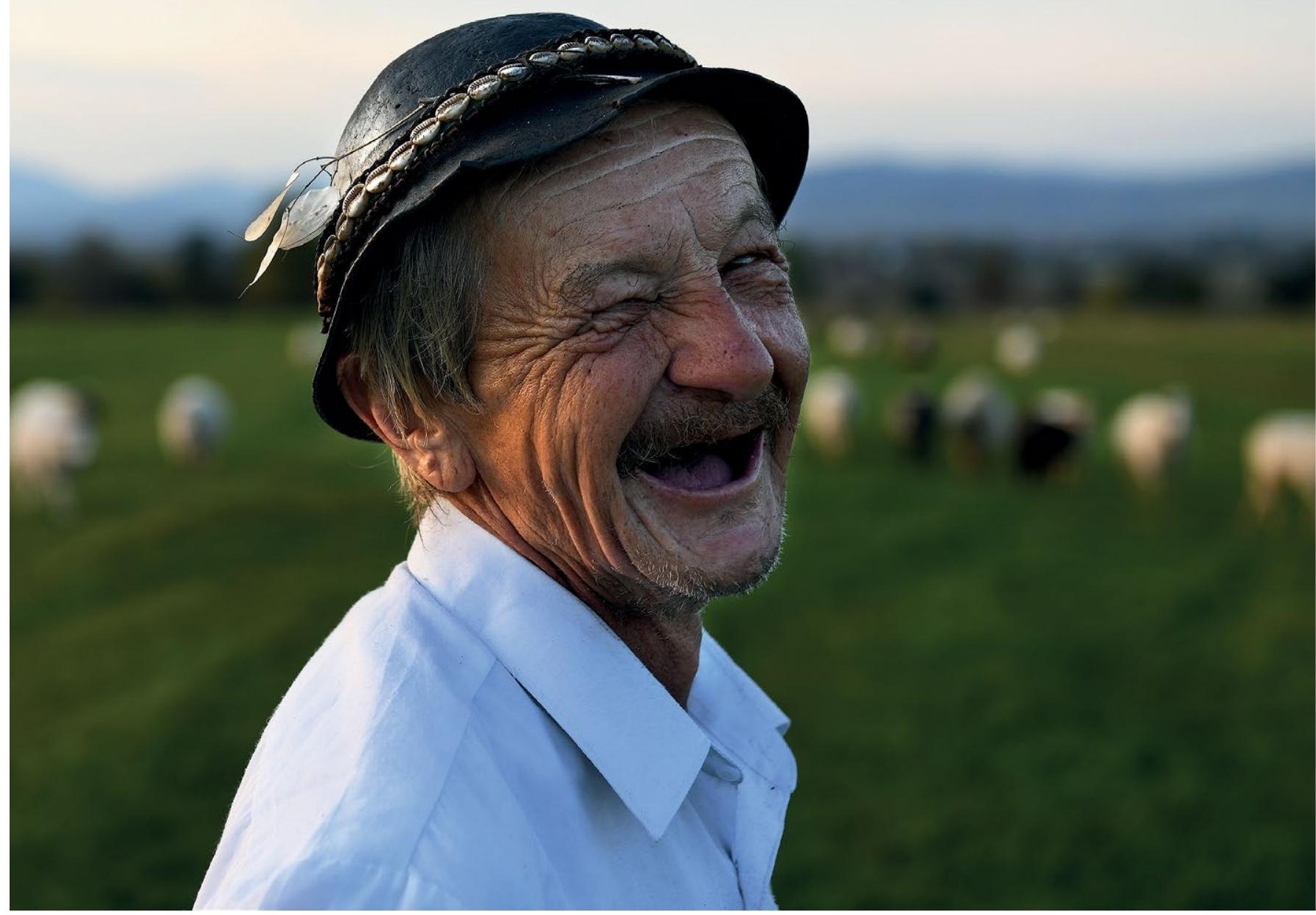

2. Bartłomiej Jurecki, Stare Bystre. Juhas Stanisław Bielański Chlebek w swoim żywiole, 2020

Na zdjęciu uwiecznione zostało stado liczące prawie 2000 owiec, prowadzone przez bacę Józefa Klimowskiego z juhasami. Zarówno zwierzęta jak i kroczący dumnie na ich czele baca są fotogeniczni! Na każdym zdjęciu prezentują się dobrze.

Fotografuję redyk, bo jest to dla mnie fenomen żywej tradycji i fenomen tego miejsca. Boję się, że niedługo tego fenomenu już nie będzie. Myślę, że jako fotograf mam obowiązek pokazać, że tradycja ta jest na tyle efektowna, że warto, żeby trwała. Podjąłem się nawet ryzyka szantażu wobec młodych górali - często na redyku namawiam ich, żeby byli też za rok, bo ludzie ich oglądają na Fejsbuku. Jeżeli mam szansę przeciągnąć tę tradycję o kilka lat, to czemu nie?!

\section{W jednym z wywiadów powiedział}

\section{Pan, że chce „promować nasze kochane}

Podhale" - w jaki sposób?

Tradycja łączy się z promocją. Mało jest w Polsce takich miejsc jak tu, gdzie na co dzień można zobaczyć ludzi ubranych w strój regionalny, idących ulicą na zakupy. Może znajdzie się kilka takich miejsc w Polsce, gdzie się tak przebiera, idąc np. do kościoła czy przy innej ważnej okazji, ale ja jestem zafascynowany, chociaż jestem góralem i tu mieszkam, że mogę zobaczyć młodą dziewczynę w stroju góralskim, która idzie 
się przejść i spotkać z koleżankami, albo starsze panie jadące na rowerze do kościoła. Krajobraz dookoła nas się zmienia, ale ludzie pozostają tacy sami. I mam nadzieję, że tradycja ich świętowania pozostanie. To jest właśnie dla mnie fenomen tego miejsca.

\section{A Pan nosi strój góralski?}

Mam zdjęcie w stroju góralskim jako mały chłopiec, miałem pięć, może sześć lat. Wyrosłem z niego, kolejnego już nie nosiłem, ale z ludźmi mówiącymi czystą gwarą dogaduję się ich gwarą. Czasem przekląć lubię też - tak po góralsku.

\section{Pejzaż i przyroda tatrzańska rów-} nież są tematami Pańskich zdjęć. I ludzie wyrzeźbieni naturą. Pan sam także odczuwa wpływ natury...

Jestem miłośnikiem przyrody. Bardziej szanuję przyrodę i lepiej się w niej odnajduję niż między ludźmi. Szczególnie teraz, kiedy Polacy są tak podzieleni, że każda rozmowa może skończyć się konfrontacją. Pracuję w mediach, muszę więc o tym czytać, słuchać, odbierać reakcje i emocje ludzi, którzy nie zawsze są pozytywnie nastawieni do dziennikarzy. To, że jestem tutaj, w tym miejscu, wynika więc z mojej dużej miłości do natury. Gdyby tak nie było, mieszkałbym pewnie w innym miejscu na świecie, gdzie więcej by się działo rzeczy interesujących dla reportera.

Kocham przyrodę, kocham zwierzęta, w ich towarzystwie najlepiej się czuję. Widzę teraz przez okno, jak mgły otulają Giewont, jak się unoszą na drzewach, nad lasem, jak sobie leżą i chodzą cały czas. I to jest widok, który nawet w najgorszej depresji zawsze polepsza nastrój. To jest kwintesencja tego, co czuję, ja się spełniam w tym miejscu i tutaj odpoczywam. Jednak nie określiłbym siebie jako fotografa górskiego, fotografa Tatr. Ja dokumentuję to, co się tutaj dzieje. To, że czasem sfotografuję pięknie oświetlone góry, jest przypadkiem, bo akurat w tym miejscu jestem. Chodzę w góry, żeby się spełnić w przyrodzie i żeby odpocząć, i to chyba rozumie każdy, kto też kocha przyrodę.

\section{Świat na Pańskich zdjęciach jest} przeważnie kolorowy. Sporadycznie decyduje się Pan na estetykę czarno-białej fotografii.

Jestem romantykiem, marzycielem, bujam w obłokach i lubię kolory wokół siebie. Czerń i biel mnie smucą. Wolę kolor. Daje moc fotografii. Kolorowe niebo, różowe chmury, światło padające na szczyty budzą zachwyt, a czerń i biel z reguły rodzi niepokój. Staram się skali szarości nie używać. Jest jednak kilka zdjęć, gdzie kolor nie ma znaczenia, np. we wnętrzu bacówki, gdzie decydujący jest kontrast, górale mają białe koszule, światło wpada przez okienko i stwarza naturalny kontrast (il. 4). Albo w przypadku nocnego zdjęcia niedźwiedzi, gdzie wykorzystałem monochromatyczność dla skorygowania balansu bieli.

Podczas naszej rozmowy zauważył Pan, że krajobraz wokół Pana się zmienia. Jak się wydaje, zmiany te nie zawsze ocenia Pan pozytywnie. Przypomnijmy, że swoimi zdjęciami bezlitośnie obnażał Pan chaos estetyczny panujący w przestrzeni publicznej Zakopanego.

Ma Pani zapewne na myśli projekt fotograficzny dotyczący Krupówek. To jest moja ulica, mieszkałem przy niej przez 30 lat, tam się bawiłem, tam wracałem ze szkoły, wiem jak się zmieniała, obserwowałem, jak rozwijał się na niej kicz. I bardzo mi się to nie podobało. Rok czy dwa po zrobieniu zdjęcia² (il. 5, s. 19) Krupówki zaczęły się zmieniać. Młodzi zakopiańczycy stworzyli projekt made in Zakopane, mający na celu utworzenie na Krupówkach parku kulturowego. I to się udało. Tego

2 Zdjęcie powstało w 2013 r. 


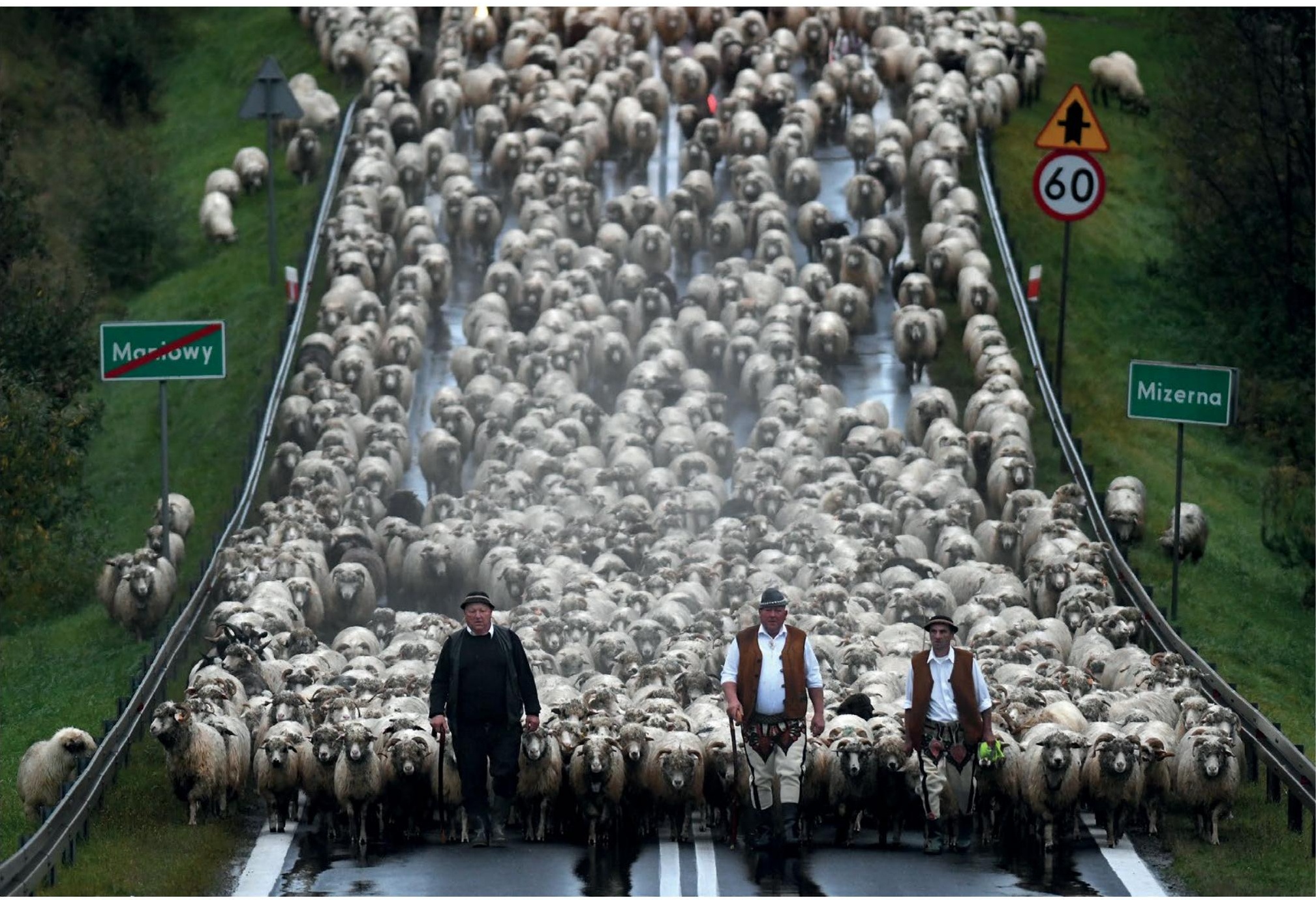

uwiecznionego przeze mnie Las Vegas już nie ma - tego kiczu i wielkich reklam świecących w każdym kolorze. Ostatnio często fotografuję pustki na Krupówkach albo tłumy ludzi - w zależności od zmieniających się pandemicznych obostrzeń, ale czuję, że Krupówki wracają do stanu, który zawsze mi się podobał: elegancji, czystości, klimatu miasta górskiego, po którym można spacerować z przyjemnością.

\section{W przypadku Krupówek odnieśli-} ście Państwo - jako zakopiańczycy - wymierny sukces. Czy oznacza to, że można już być spokojnym o losy tej ulicy i całego miasta?
W kwestii zabudowy i urbanistyki Zakopane trochę błądzi. Mamy mnóstwo budynków, które nie wyglądają dobrze na tle Tatr, które gabarytami zasłaniają góry. Kolejnym zjawiskiem jest „pandemia domkowa”, wysyp małych, drewnianych kwater na wynajem. Niektóre są ładne, inne brzydsze, ale jest ich coraz więcej, zajmują te skrawki zieleni, po których można było spacerować. Jest to plaga i problem przyszłości: będzie pięknie u góry, a koszmarnie na dole.

Przyznam, że w obliczu tych procesów czujemy się bezsilni. Piętnaście lat temu fotografowałem na Antałówce siedmiopiętrowy budynek. Postawiony 
4. Bartłomiej Jurecki, Tradycyjna góralska bacówka w pełni sezonu, 2013

nielegalnie, przesłaniający panoramę gór. Nadal stoi i funkcjonuje.

Chciałbym, żeby nowe inwestycje zwłaszcza te duże - były realizowane w sposób nawiązujący do tradycji. Niech inwestor wykorzysta miejscowych twórców, mamy przecież szkołę im. Antoniego Kenara! Ci młodzi ludzie wymyślają takie cuda, które będziemy podziwiać jeszcze przez lata i które zostaną tu na stałe. Dobrze by było, żeby wnętrzami i dekoracją architektoniczną zajęli się artyści od nas, bo oni znają i rozumieją tradycję.
Bartłomiej Jurecki pochodzi z Zakopanego. Jest absolwentem Krakowskiej Szkoły Artystycznej i Państwowej Wyższej Szkoły Filmowej, Telewizyjnej i Teatralnej w Łodzi, gdzie uzyskał tytuł magistra fotografii. Na co dzień fotografuje dla "Tygodnika Podhalańskiego".

Jest laureatem konkursów:

Polska:

Grand Press Photo (sześciokrotnie), BZ WBK Press Foto (ośmiokrotnie), Leica Street Photo (dwukrotnie), Wielki Konkurs National Geographic Polska (trzykrotnie), Fotoreporter Roku (pięciokrotnie), SGL Local Press (pięciokrotnie), Nagroda Dziennikarzy Małopolski (dwukrotnie), Polski Konkurs Fotografii Sportowej Świat:

Pictures of the Year International, NPPA Best of Photojournalism, Insight Astronomy Photographer of the Year, National Geographic Traveler Photo Contest, Vincent Van Gogh Photo Award, Pxз Prix de la Photographie Paris, FEP European Professional Photographer of the Year (dwukrotnie), IPA International Photography Awards (czternastokrotnie),
A Zakopane ma przecież długą i chlubną tradycję owocnej współpracy pomiędzy odpowiedzialnymi inwestorami a lokalnym środowiskiem artystycznym. Ma też, jak widzę, realne wsparcie wśród mieszkańców, świadomych wartości i unikatowości Waszego dziedzictwa. Dzięlkując Panu za rozmowę, życzę kolejnych osiągnięć w utrwalaniu, promowaniu i ochronie podhalańskich tradycji.
Event Photography Awards (trzykrotnie), Kuwait Grand Photography Contest (dwukrotnie), dotART Urban International Photo Contest, Siena International Photography Awards (dwukrotnie), Black \& White Spider Awards (dwukrotnie), PCOI - CHIIZ Photography Club of India, Life Framer, Moment Street Photo Awards Jest również finalistą konkursów:

Sony World Photography Awards, The Miami Street Photography Festival, Portrait of Humanity, Weather Photographer of the Year, Hamdan International Photography Awards (HIPA), StreetFoto San Francisco, International Mountain Summit Photo Contest, Travel Photographer of the Year, Prasowe Zdjęcie Roku (dwukrotnie), Konkursu SDP im. Erazma Ciołka (pięciokrotnie), Konkursu SDP im. Eugeniusza Lokajskiego, Memorial Maria Luisa, Malta International Photo Award, LensCulture Street Photography Awards Top 100.

www.jurecki.com

www.facebook.com/bartlomiejjurecki www.instagram.com/bartlomiejjurecki 


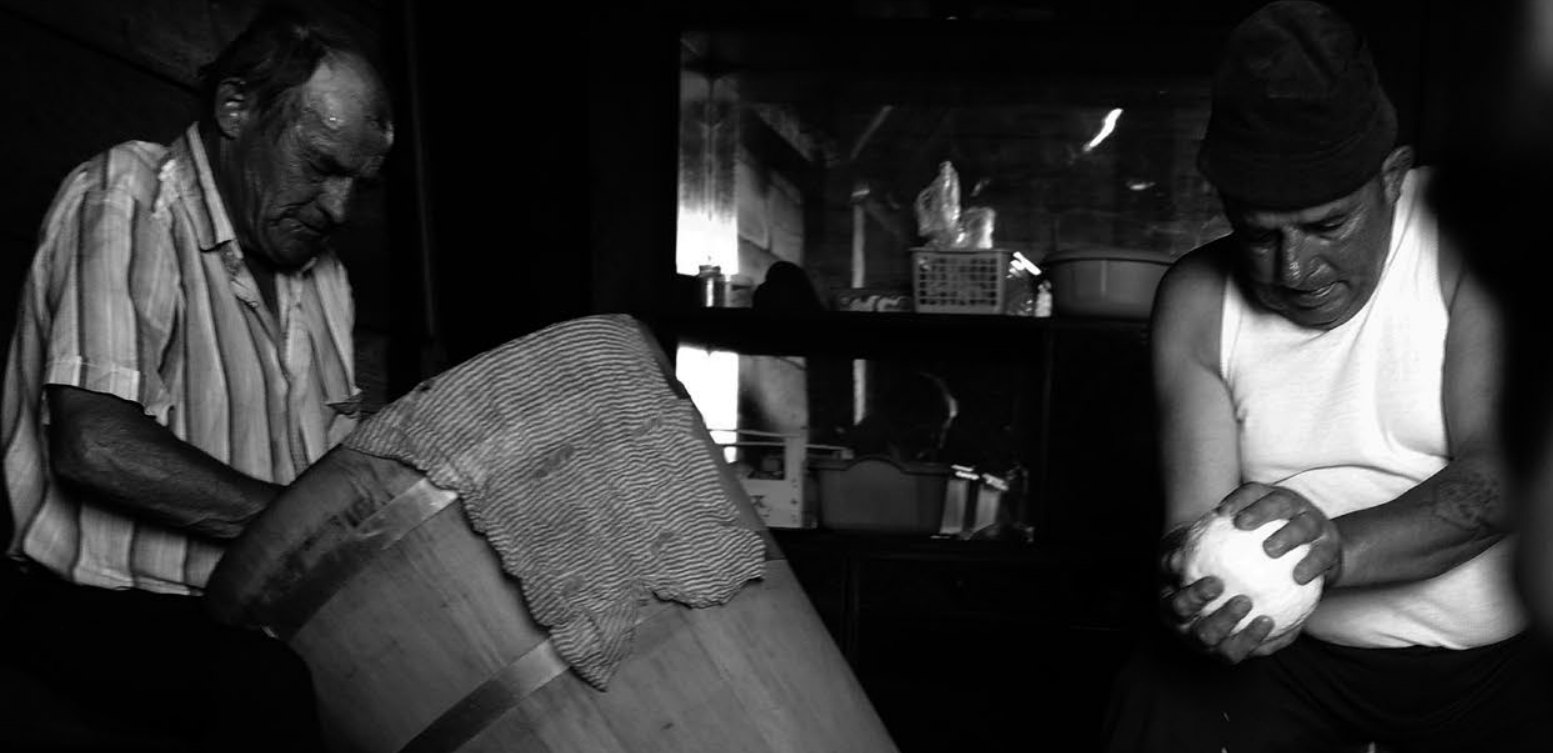

